\title{
Physico-chemical properties of west Khasi Hills soils of Meghalaya in relation to land uses
}

\author{
MANOJ DUTTA, JANSHAIPHARSTEP DIENGDOH AND SEWAK RAM
}

\author{
MEMBERS OF RESEARCH FORUM: \\ Corresponding author : \\ MANOJ DUTTA, Department of Soil \\ and Water Conservation, School of \\ Agricultural Sciences and Rural \\ Development, Nagaland University, \\ Medziphema Campus, MEDZIPHEMA \\ (NAGALAND) INDIA \\ E mail: anojdutta1997@yahoo.com \\ Co-authors : \\ JANSHAIPHARSTEP DIENGDOH AND \\ SEWAK RAM, Department of Soil \\ and Water Conservation, School of \\ Agricultural Sciences and Rural \\ Development, Nagaland University, \\ Medziphema Campus, MEDZIPHEMA \\ (NAGALAND) INDIA
}

Received : 23.10.2015; Revised : 11.11.2015; Accepted : 26.11.2015

\section{Summary}

The effect of land use on soil physico-chemical properties were studied in four villages, viz., Nongstoin, Kynshi, Umyiap and Maweit in West Khasi Hills district, Meghalaya, under four land uses, viz., paddy, potato, forest and jhum land, in each village. The soils of the study area were acidic in reaction, high in organic carbon and low to medium in cation exchange capacity. Bulk density and particle density were lower in surface soils as compared to sub-surface soils except in some locations. The water holding capacity was greatly influenced by mechanical composition and organic matter content in soils. The mean weight diameter and per cent aggregation showed similar trend and were significantly correlated. Hydraulic conductivity under potato and jhum land uses was higher than paddy and forest land uses.

Key words : Land uses, Physico-chemical properties, Surface and sub surface soil

How to cite this article : Dutta, Manoj, Diengdoh, Janshaipharstep and Ram, Sewak (2015). Physicochemical properties of west Khasi Hills soils of Meghalaya in relation to land uses. Asian J. Soil Sci., 10(2) : 288-294. 